NBER WORKING PAPER SERIES

\title{
ILLICIT DRUG USE AND EDUCATIONAL ATTAINMENT
}

\author{
Pinka Chatterji \\ Working Paper 10045 \\ http://www.nber.org/papers/w10045 \\ NATIONAL BUREAU OF ECONOMIC RESEARCH \\ 1050 Massachusetts Avenue \\ Cambridge, MA 02138 \\ October 2003
}

I gratefully acknowledge research support from grant K01 AA000328-03 from the National Institute of Alcohol Abuse and Alcoholism. I would like to thank the National Bureau of Economic Research for providing data on marijuana policies and cocaine prices. The views expressed herein are those of the authors and not necessarily those of the National Bureau of Economic Research.

(C2003 by Pinka Chatterji. All rights reserved. Short sections of text, not to exceed two paragraphs, may be quoted without explicit permission provided that full credit, including (C) notice, is given to the source. 
Illicit Drug Use and Educational Attainment

Pinka Chatterji

NBER Working Paper No. 10045

October 2003

JEL No. I1

\title{
$\underline{\text { ABSTRACT }}$
}

This paper uses data from the National Education Longitudinal Study to estimate the association between illicit drug use during high school and the number of years of schooling completed. The analysis accounts for the possibility that drug use is endogenous using two methods: (1) by controlling for individual-level characteristics measured before high school entrance; and (2) by using an instrumental variables method, with state drug policies and 8th grade school characteristics as identifying variables. Findings suggest that marijuana and cocaine use in both 10 th and 12 th grade are associated with reductions in the number of years of schooling completed.

\author{
Pinka Chatterji \\ Center for Multicultural Mental Health Research \\ Cambridge Health Alliance \\ Harvard Medical School \\ 120 Beacon Street, 4th Floor \\ Somerville, MA 02143 \\ and NBER \\ pchatterji@charesearch.org
}


Illicit drug use among youth is a pressing public health problem at the national, community, and school level (Johnston et al. 2002; U.S. Department of Justice 2001). Rates of use have increased considerably since 1991 , when about 12 percent of $10^{\text {th }}$ grade students and 16 percent of $12^{\text {th }}$ grade students reported any illicit drug use in the past month. As of 2002, 21 percent of $10^{\text {th }}$ grade students and 25 percent of $12^{\text {th }}$ grade students reported past month illicit drug use (Johnston et al. 2002). The recent increase in illicit drug use among youth has led to concern about both the short-term and the long-term consequences of this risky behavior (ONDCP 2003).

Part of the concern about adolescent substance use stems from the idea that drug use interferes with the rapid accumulation of social, emotional and academic skills that normally takes place during adolescence. Drug use has the potential to detract from motivation, cognition, and memory as well as the potential to exacerbate existing mental disorders, all of which can affect academic performance (Hawkins et al. 1992, Brook et al. 1999). It is widely believed that drug use leads to academic failure, and, at first glance, the empirical evidence supports this viewpoint. Adolescent marijuana users, for example, are about twice as likely as non-users to drop out of high school, perform worse than non-users on some standardized achievement tests, and are much more likely than non-users to report poor academic performance. (Brook et al. 1999; Bray et al. 2000; Yamada et al. 1998, Diego et al. 2003, Pacula et al. 2003a).

The relationship between substance use and academic outcomes, however, clearly has the potential to be bidirectional. While substance use during adolescence is associated with later academic problems, early school failure and low attachment to school have been identified as 
leading risk factors for substance use, as well as good predictors of low educational attainment in the future, independent of drug use (Hawkins et al. 1992, Jessor \& Jessor 1978). Substance use appears to be both a cause and a result of academic problems, and disentangling these pathways is an empirical challenge.

The objective of this study is to use data from the Fourth Follow-up to the National Education Longitudinal Study of 1988 (NELS 2000) to explore the causal relationship between illicit drug use during high school and the number of years of schooling completed by 2000 , when most respondents are about 26 years old. The analysis focuses on using two methods to account for the possibility that illicit drug use is correlated with unobserved factors that also influence educational attainment. The first method uses student characteristics measured before high school to control for preexisting factors that may confound an observed association between high school drug use and educational attainment. The second method is an instrumental variables approach, with state and school-level drug policies as identifying instrumental variables. Both of these empirical approaches take advantage of the unusually rich personal and school-level information that is available for NELS respondents before, during and after high school.

This study is the first to estimate using national data the effect of illicit drug use on educational attainment, while directly addressing the possibility that drug use is endogenous. The findings suggest that past month marijuana use in $10^{\text {th }}$ or $12^{\text {th }}$ grade is associated with a reduction in educational attainment at age 26 of about 0.2 to 0.3 years, while lifetime cocaine use by 10 or $12^{\text {th }}$ grade is associated with a reduction in attainment of about 0.2 to 0.4 years. However, there is evidence of some selection into drug use along observed variables, which may imply selection into drug use along unobserved factors that also affect educational attainment. 
The IV results, which account for this problem, provide suggestive, but not conclusive, evidence that some of the associations between drug use and educational attainment represent causal relationships.

\section{Is the association between substance use and educational attainment causal?}

Psychologists have long debated whether or not drug use, low educational attainment, and other problem behaviors are caused by a common, psychological factor, such as an unobserved propensity towards deviant behavior (Jessor \& Jessor 1977, Newcomb \& Bentler 1988). Empirically, it is clear that drug use and academic failure share some common, measurable antecedents at the individual level, such as misbehavior and lack of interest in school, mental disorders like attention deficit hyperactivity disorder (ADHD) and depression, deviant peer group, and early antisocial behavior (Bryant et al. 2003, Molina \& Pelham 2003, Slater 2003, DeWitt 2002, Griffin et al. 2002; Field et al. 2001, Jessor \& Jessor 1978, Flewelling \& Bauman 1990, Bachman et al. 1991, Jeynes 2001, Brandon 2000, Bryant et al. 2003; Sale et al. 2003). The existence of many measurable, common risk factors may suggest that unobserved risk factors confound the negative association between drug use and educational attainment. In this case, a strong correlation between drug use and low educational attainment may not reflect a causal relationship.

Some previous researchers in health economics have investigated the causal link between substance use in high school and educational attainment. These researchers have focused on alcohol use. Cook and Moore (1993), for example, use data on high school seniors from the National Longitudinal Survey of Youth (NLSY) and an instrumental variables methodology to study the impact of frequent drinking (drinking on at least two days in the past week) on the number of years of education completed. Using state-level alcohol policies as instruments, they 
find that seniors who are frequent drinkers complete 2.3 fewer years of college compared to seniors who are not frequent drinkers (Cook and Moore 1993).

More recently, Koch \& Ribar (2001), also using a sample from the NLSY, estimate the effect of the age of initiation of alcohol use on the number of years of schooling completed by age 25. They demonstrate that state-level alcohol policies are not good predictors of alcohol use initiation, which casts doubt on their value as identifying variables in this case. As an alternative approach, they take advantage of data on siblings and estimate: (1) family fixed effects models; and (2) instrumental variables models using sibling age of alcohol use initiation as an instrument. The findings suggest that at most, the age of alcohol use initiation increases the years of schooling completed by 0.47 years for men and by 0.36 years for women. This upper bound result comes from the sibling IV model, which relies on the assumption that each respondent's sibling's age of drinking initiation is exogenous to the model. As the authors acknowledge, this assumption is difficult to defend, as many unobserved family and environmental characteristics, such as a family history of alcoholism, are likely to affect both siblings' drinking behaviors and educational outcomes.

Dee \& Evans (2003) use another approach to circumvent the problem of weak identifying variables. They use pooled data from the 1977-92 Monitoring the Future surveys to estimate the impact of minimum drinking ages on drinking, and data from the Census Bureau's 1990 Public Use Sample to estimate reduced form equations modeling the effect of drinking ages on schooling. Using a two-sample IV strategy, they draw on both sets of results to generate estimates of the impact of drinking on educational attainment (see Dee \& Evans 2003 for details of the methodological approach). Dee and Evans (2003) report that none of the alcohol use 
measures have a statistically significant impact on high school completion, college entrance or college persistence.

Two previous studies in the health economics literature focus on estimating the effect of marijuana use on high school completion. Bray et al. (2000), using data on 1,392 students from a southeastern US public school system, report that marijuana initiation during high school more than doubles the odds of high school dropout. Similarly, Yamada et al. (1996), based on data on high school seniors from the National Longitudinal Survey of Youth (NLSY), find that recent marijuana use is associated with a lower probability of graduation. These results are consistent with findings from the psychology and sociology literature, which suggest that marijuana and other illicit drug use detract from the likelihood of high school completion (Kandel \& Davies 1996; Newcomb \& Bentler, 1985, 1986).

However, none of these studies on illicit drug use adequately address the issue of whether drug use is a cause or just a correlate of high school dropout. If students who use drugs disproportionately have behavior problems, academic deficiencies or disadvantaged backgrounds, they may not have graduated from high school even if they hadn't used drugs. Yamada et al. (1996) do not present results from models where the endogeneity of drug use is directly addressed. It is notable that Bray et al. test for endogeneity of drug use in their models, and they find no evidence of this problem. Unfortunately, this study does not report information about the identifying variables used to generate these results. This issue is important since their data come from a single school system, and it is not clear from where they obtain exogenous variation in drug availability.

This paper contributes to the existing literature on illicit drug use and educational attainment in several ways. First, this study uses empirical methods that address the possibility 
that high school students select into illicit drug use based on unobserved characteristics that also affect their educational outcomes. This significant empirical problem has been recognized in numerous, related studies that have focused on alcohol and schooling (see Cook \& Moore 1993; Dee \& Evans 2003; Koch \& Ribar 2001), and illicit drug use and labor market outcomes (see DeSimone 2003; Kaestner 1991, 1994). However, to date, no study on illicit drug use and educational attainment using national data has adequately accounted for the possibility that illicit drug use is endogenous.

This study also builds on previous work by considering the effects of both marijuana and cocaine use, while the two previous health economics papers only consider marijuana. Although cocaine use is still uncommon among high school students, the past month prevalence of cocaine use among $10^{\text {th }}$ graders more than doubled between 1991 and 2002 (Johnston et al. 2002). Given this dramatic increase in use, it is important to understand how cocaine use affects educational attainment.

Finally, this study considers as an outcome the number of years of schooling completed. This educational outcome measure is more informative than a dummy variable indicating high school dropout since substance use might affect post-secondary educational attainment as well as high school completion. Moreover, because educational attainment is measured around age 26, when most young people have completed their education, this study sheds some light on the long-term consequences of illicit drug use during high school.

\section{Methods: Addressing the Endogeneity Problem}

Previous health economics research on alcohol use (Dee \& Evans 2003), along with extensive theory and empirical evidence from the psychology literature (see Hawkins et al. 1992 for a review), suggest that students who use substances during high school enter high school with 
individual and family characteristics that predispose them to low educational attainment. Empirically, this issue becomes a problem because researchers using secondary data sets typically cannot control for all of the important preexisting variables that are linked to substance use and educational outcomes. If an unobserved factor exists that is correlated with drug use and also directly related to educational attainment, standard estimation methods may yield biased and inconsistent estimates of the effect of drug use on educational attainment. The goal of the empirical approach used in this paper is to test for and address this problem, first by using student characteristics measured before high school, and next by using an instrumental variables method.

More formally, consider a linear specification of the structural human capital production function $(\mathrm{H})$ and a linear specification of the demand function for drugs $(\mathrm{D})$ :

$$
\begin{aligned}
& \mathrm{H}=\alpha_{1} \mathrm{D}+\alpha_{2} \mathrm{X}+\alpha_{3} \mu+\varepsilon \\
& \mathrm{D}=\beta_{1} \mathrm{X}+\beta_{2} \mathrm{Y}+\beta_{3} \mu+\eta .
\end{aligned}
$$

Equation (1) represents a production function for educational attainment $(\mathrm{H})$. Educational attainment is a function of substance use (D), observed characteristics such as gender and race $(\mathrm{X})$, and unobserved variables such as motivation $(\mu)$. Equation (2) represents the demand for illicit drugs. The vector $\mathrm{X}$ represents observed characteristics that affect substance use, which are the same as the observed determinants of educational attainment, while the vector $\mathrm{Y}$ consists of prices and policies that affect the availability of substances to youth. The vector $\mu$ represents the unobserved determinants of educational attainment that also may influence illicit drug use. The terms $\varepsilon$ and $\eta$ represent random disturbance terms, and intercepts are suppressed for convenience. 
The parameter of interest is $\alpha_{1}$, the structural effect of substance use on educational attainment. However, estimating equation 1 by standard methods can lead to biased and inconsistent coefficients if substance use is determined by the same unmeasured characteristics that determine one's educational attainment $\left(\alpha_{3} \neq 0\right.$ and $\left.\beta_{2} \neq 0\right)$. In this case, estimating the coefficients by a standard OLS model would violate a central assumption underlying the classical linear regression model framework, which is that the right-hand side variables should be exogenous with respect to the error term (Greene 2003).

The first approach used in this paper to deal with this problem is to use data on observed characteristics to: (1) assess the importance of selection on observed characteristics; and (2) to proxy $\mu$ to the fullest extent possible, mainly by controlling for a number of important differences between students that preceded high school entrance. ${ }^{2}$ First, Equation (1) is estimated using an OLS regression model without any control variables (Model 1). Next, the model is estimated with a standard set of family background and demographic characteristics that have been linked to educational attainment in previous studies (Model 2). If students select into drug use along family background characteristics that also affect educational attainment, the magnitude of the estimated drug use coefficient should change appreciably when these variables are included in the model. Comparing the estimated coefficient on drug use in Models 1 and 2, therefore, provides information about the degree of selection along observed family background characteristics.

Following the same reasoning, Model 2 is then estimated with the addition of a set of student and school characteristics measured during high school (Model 3). Drug use is known to be correlated with other concurrent problem behaviors and school/community deficiencies, 
which themselves may have independent impact on educational attainment (Jessor \& Jessor 1977; Hawkins et al. 1992). If the observed association between drug use and educational attainment is confounded by other, current problematic behaviors or high school characteristics, the estimated coefficient on drug use would be expected to decline in magnitude once these variables are included.

The NELS data set is unique in that it provides detailed information about respondents in $8^{\text {th }}$ grade, before they entered high school. Adolescents who use drugs during high school are more likely than non-users to enter high school with preexisting problem behaviors, such as early academic failure, smoking, and behavior problems (Hawkins et al. 1992). These factors may detract from educational attainment regardless of drug use status in high school. To determine the degree of selection on preexisting factors, the educational attainment equation is estimated with the addition of a set of $8^{\text {th }}$ grade personal characteristics (Model 4). If the relationship between high school substance use and educational attainment is causal, controlling for $8^{\text {th }}$ grade risk factors for drug use should not substantially reduce the magnitude of the estimated drug use coefficient. Previous studies of illicit drug use and educational attainment have not been able to control for these preexisting characteristics of students because of insufficient data.

The approach outlined thus far is based on the assumption that adolescents select into drug use based on measurable characteristics that also may affect their educational attainment. However, despite the rich, longitudinal data available in NELS, it is still possible that important unmeasured factors exist that affect both drug use and educational attainment. In particular, NELS does not have clinical information on mental disorders, such as depression and attention deficit hyperactivity disorder. These mental disorders are known to be correlated with both

2 This approach draws on the work of Painter \& Levine (2000), who use NELS to study the effect of family 
substance use and academic problems (Molina \& Pelham 2003, Diego et al. 2003). Although existing data on smoking and behavior problems is used to proxy mental disorders, it is still possible that this factor, or another important confounder, remains in the error term.

For this reason, the educational attainment model is estimated using an instrumental variables (IV) method, which purges the potentially endogenous drug use variable of its correlation with the error term. The IV models are estimated with a set of basic family and demographic covariates that are exogenous from the youth's perspective, and with a full set of covariates that includes potentially endogenous variables such as smoking and behavior problems. The endogeneity of drug use with respect to educational attainment is tested using the Durbin-Wu-Hausman test, and all models are estimated using robust standard errors that account for clustering of observations at the state level. Additionally, the validity of the over-identifying restrictions is tested, and the predictive power of the identifying instrumental variables is assessed. The drug use equation has a binary dependent variable, but it is estimated as a linear probability model for computational convenience.

The practical challenge of implementing the IV method is that it requires valid exclusion restrictions - variables that affect substance use, but that are also exogenous and not directly related to educational attainment. Measures of state-level illicit drug use prices (marijuana decriminalization policy ${ }^{3}$, statutory jail terms for marijuana possession, fines for marijuana

structure on youths' outcomes.

${ }^{3}$ The following states had decriminalized marijuana during the time period when NELS respondents were in high school: Alaska, California, Colorado, Maine, Minnesota, Mississippi, Nebraska, New York, North Carolina, Ohio and Oregon. Pacula et al. (2003) demonstrate that marijuana decriminalization policy captures something other than more lenient consequences for marijuana possession. Instead, these researchers suggest that decriminalization may proxy greater public awareness about marijuana policy or social acceptance of marijuana use. Because the interpretation of this policy is potentially problematic, the models in this paper are estimated with and without marijuana decriminalization included as an identifying instrument. 
possession, and cocaine prices) are used as identifying variables. State-level drug policies are expected to be good predictors of adolescent substance use, but they are not expected to directly affect educational attainment or to be correlated with the disturbance term. However, in the instrumental variables (IV) context, these policy variables sometimes are poor predictors of substance use. Bound et al. (1995), Bollen et al. (1995), Nelson \& Startz (1990) and others show that a low first stage F-statistic for the identifying instrumental variables may suggest that IV estimates are no better than biased OLS estimates.

In addition to these concerns about predictive power, Dee (1999) suggests that state substance use policies may be associated with unobserved state sentiments that are correlated with both substance use and the consequences of substance use. For example, a state whose residents have higher than average concern and involvement in youth development and education may enact particularly stringent alcohol and illicit drug policies. In this case, state substance use policies are no longer exogenous and therefore cannot serve as identifying instrumental variables. As an alternative, Dee (1999) suggests estimating models that include state fixed effects and relying on within-state variation in policies for identification. In addition to these problems with alcohol policies which have been highlighted in the alcohol use literature, illicit drug prices may be measured with error and they are inherently more difficult to quantify than alcohol prices and policies.

For these reasons, the IV models are also estimated using a set of identifying variables that capture the availability of drugs in each student's $8^{\text {th }}$ grade school. The availability of drugs is captured by the $8^{\text {th }}$ grade school principal's perception of whether or not drugs are a moderate to serious problem at the school, and whether or not the school has a policy of expelling students if they are caught with illegal drugs on school property. If the $8^{\text {th }}$ grade school principal believes 
that drug use is a problem, or if the $8^{\text {th }}$ grade school policy for drug possession is not stringent, these features of the school environment may indicate relative availability of drugs at school. ${ }^{4}$ These school-level variables are expected to be good predictors of drug use in high school since students who have drugs available to them in $8^{\text {th }}$ grade may be more likely than others to use drugs and to continue use during high school (Kandel 1975, Morral et al. 2002).

The availability of drugs in $8^{\text {th }}$ grade is not expected to directly affect educational attainment at age 26, conditional on the availability of drugs in $10^{\text {th }}\left(\right.$ or $\left.12^{\text {th }}\right)$ grade and the student reaching $10^{\text {th }}$ (or $12^{\text {th }}$ ) grade. The educational attainment equation includes the same two $8^{\text {th }}$ grade drug availability variables - drug use is a problem at school and punishment for drugs is expulsion -- measured in high school. In other words, the use of these $8^{\text {th }}$ grade variables as identifying instruments assumes that the school drug environment in $8^{\text {th }}$ grade may affect drug use in $10^{\text {th }}\left(\right.$ or $\left.12^{\text {th }}\right)$ grade and academic performance until $10^{\text {th }}\left(\right.$ or $\left.12^{\text {th }}\right)$ grade.

However, once the student has made it as far as high school, the high school drug environment is assumed to supersede the junior high school environment.

This exclusion restriction presumes that the $8^{\text {th }}$ grade drug environment does not affect final educational attainment at age 26 , conditional on the high school drug environment (and all the other factors measured in high school) and conditional on the student reaching $10^{\text {th }}$ (or $\left.12^{\text {th }}\right)$ grade. Although the analysis includes tests to determine the empirical validity of these schoollevel identifying variables, this assumption is still less theoretically appealing than the assumptions used to justify state-level policies as identifying instruments. School-level factors, on the other hand, may be better predictors of high school drug use than drug prices measured at

\footnotetext{
${ }^{4}$ It is possible that school drug policy is endogenous in that school policymakers design policies based on the degree to which drug use is a problem at the school. The estimated correlation coefficient between having a policy of
} 
the state level since the school environment is one the most important contexts for adolescents, along with family and peers (Hawkins et al. 1992).

Both the state-level variables and the school-level variables are potentially problematic as identifying instruments. The use of cross-sectional variation in state-level policies for identification has been controversial in the alcohol use and educational attainment literature. State-level drug policies in particular (but also school policies) may be correlated with unobserved state-level factors that affect educational attainment. State policies also may be poor predictors of drug use. School-level drug availability measures are likely to be better predictors of drug use, but it is possible that they have direct impact on educational attainment.

This paper deals with this issue in two ways. First, to control for state-level factors that may be correlated with state-level and school-level drug policies, the models are estimated with and without a set of state-level variables included that are thought to proxy state sentiment. These variables are dummy indicators for the religious composition of state, the state unemployment rate, and the state's average real income. If the estimates are sensitive to the inclusion of these state-level variables, this finding suggests that state-level sentiment may affect both drug policies and educational attainment. This strategy is the best solution in the absence of longitudinal data that would allow state-level fixed effects.

Second, the analysis tests both sets of instruments (separately and together) for predictive power and to see if they can be validly left out of the educational attainment equation. The IV results are useful only if the identifying instruments as a group are reasonably strong predictors of drug use, and if they can be validly excluded from the educational attainment equation. The 
IV models also are estimated with both the school-level and state-level variables as instruments, and then separately with just the school-level and just the state-level variables as instruments. This approach allows one to gauge whether or not the instruments are appropriate, and whether or not the results are sensitive to which instruments are used to identify the model. The IV models also are estimated with a small and a larger set of covariates to determine whether the estimates are sensitive to model specification.

\section{The National Education Longitudinal Study}

Data come from the National Education Longitudinal Study (NELS), an education survey designed to study the high school students of the 1990's. The study is unique in that it surveys students prior to high school entry, in $8^{\text {th }}$ grade, and then follows them until the year 2000, when most respondents are 26 years old. The survey was initiated in the spring semester of 1988 , when about $25,0008^{\text {th }}$ grade students completed surveys along with their parents, teachers and school administrators. The students are a clustered, stratified probability sample of over 1,000 public and private schools. In this base-year survey, extensive information was collected about the students' school experiences, family background, activities, attitudes and smoking behavior. The students also took curriculum-sensitive cognitive tests in reading, mathematics, science and social studies. Parents, teachers and school principals completed questionnaires about the student and his/her activities, the family, teaching practices and the school (NCES 2002).

After the baseline survey in 1988, the students completed surveys four more times, in 1990, 1992, 1994, and finally, in 2000, when most respondents were about 26 years old and had been out of high school for eight years (NCES 2002). In 1990 and 1992, the samples were freshened with some new respondents to ensure that the data could be used to represent the national population of sophomores as of 1990 and the national population of seniors as of 1992. 
The survey continued to track and interview students who dropped out of high school. The weighted response rate for eighth-grade respondents by the 2000 survey was 83.8 percent (NCES 2002).

This study uses data from the 2000 follow-up of the NELS, which included 12,144 respondents from the three previous surveys. Two samples are used in the analysis: (1) a $10^{\text {th }}$ grade sample, comprised of 6,231 students who were interviewed in $8^{\text {th }}$ grade, who were still in school by 1990, and who had completed student, parent and school interviews; and (2) a $12^{\text {th }}$ grade sample, comprised of 4,008 students from the $10^{\text {th }}$ grade sample who were still in school by 1992 , and who had student and school interviews available. The $10^{\text {th }}$ grade sample is used to examine the effect of $10^{\text {th }}$ grade drug use on educational attainment among students who were still in school (but not necessarily at grade level) 2 years after the baseline interview. The $10^{\text {th }}$ grade sample includes students who dropped out of school after being interviewed in $10^{\text {th }}$ grade, but it excludes students who dropped out prior to being interviewed in $10^{\text {th }}$ grade. ${ }^{5}$ The sample also excludes students with any missing substance use information $(\mathrm{N}=1,273)$, missing information on school drug policies in $8^{\text {th }}$ or $10^{\text {th }}$ grade $(\mathrm{N}=1,229)$, missing education information in $2000(\mathrm{~N}=69)$, and missing information on state drug policies $(\mathrm{N}=136)$. There were only modest numbers of missing values for other data elements, and these missing values were imputed using sample means.

Because there were a large percentage of observations with missing data for school drug policies and for substance use, it was necessary to see whether retaining, rather than dropping, these observations affected the estimates presented in this paper. The models were estimated

\footnotetext{
${ }^{5}$ The NELS survey made great efforts to track and interview school dropouts, including early dropouts. Drug use information is available for students who dropped out of school between $8^{\text {th }}$ and $10^{\text {th }}$ grade. However, it is not clear if the drug use preceded or postdated the school dropout event. Logically, then, these early dropout respondents cannot be included in this analysis.
} 
after imputing school and state drug policies, alcohol use, and cigarette use using sample means. The OLS estimates from this analysis were very similar to the OLS estimates presented in this paper. In some cases, the IV estimates varied from those presented here, but these estimates were qualitatively very similar to those presented in this paper.

The $12^{\text {th }}$ grade sample is a sub-sample comprised of 4,008 respondents from the $10^{\text {th }}$ grade sample who were still in school two years later. This sample is used to explore the effect of drug use in $12^{\text {th }}$ grade among students who were still in school (but not necessarily at expected grade level) four years after the baseline interview. By design, the sample excludes students in the $10^{\text {th }}$ grade sample who dropped out between $10^{\text {th }}$ and $12^{\text {th }}$ grade. Because only 14 students in the sample dropped out after being interviewed in $12^{\text {th }}$ grade, the effects estimated using the $12^{\text {th }}$ grade sample are mainly the effects of $12^{\text {th }}$ grade drug use on post-secondary educational attainment. The sample excludes 490 students with missing information on $12^{\text {th }}$ grade marijuana or cocaine use, and 339 observations with missing data on school drug policies. ${ }^{6}$

This paper uses educational outcome data from the fourth follow-up survey which was conducted in 2000. Most respondents were 26 years old, and were likely by this age to have completed their education. Some respondents dropped out of high school or college, and then returned to complete their studies by 2000 . The dependent variable is the number of years of schooling completed by the 2000 interview, which ranges from 11 to 20 years in both samples. Both previous studies on illicit drug use and educational attainment have focused on a dummy indicator of high school graduation as an outcome. In this study, because data are available on educational attainment 12 years after $8^{\text {th }}$ grade, one can explore the effects of drug use on post-

\footnotetext{
6 In order to use weights to generalize to a meaningful population, the group of 12,144 students must be sub-set into a grade cohort (e.g. $10^{\text {th }}$ grade cohort). Instead, in order to include students who were not at grade level, the $10^{\text {th }}$ and $12^{\text {th }}$ grade samples in this analysis include students who repeated grades. Therefore, cohort weights are not used to generalize to a particular population.
} 
secondary attainment, as well as effects of drug use that might not be captured by a dummy variable indicating graduation.

NELS respondents answered extensive questions about their alcohol, marijuana and cocaine use during the first and second follow-up interviews, when most students were in $10^{\text {th }}$ and $12^{\text {th }}$ grade. Specifically, respondents answered questions about how many times they had consumed any alcoholic beverages in their lifetime, in the past 12 months and in the past 30 days. The illicit drug use questions included questions about marijuana and cocaine use (any form, including crack). Respondents reported the number of occasions they had used marijuana and the number of occasions they had used cocaine in their lifetime, in the past 12 months and in the past 30 days.

Marijuana and cocaine use are measured in both $10^{\text {th }}$ and $12^{\text {th }}$ grade by dummy variables indicating: (1) whether or not the respondent used marijuana at least once in the past 30 days; and (2) whether or not the respondent used cocaine at least once in his/her lifetime. ${ }^{7}$ The cocaine use measure corresponds to any lifetime use rather than any use in the past 30 days because the number of respondents reporting any past month cocaine use was very small. Because of multicollinearity between the substance use measures, the main models presented in the paper include each substance use measure separately. To gauge the sensitivity of the estimates to the inclusion of other substance use measures, some models were estimated that include illicit drug use measures with alcohol use measures.

In addition to the substance use measures, the basic models include: (1) gender; (2) race/ethnicity indicator variables; (3) region of residence; (4) religion indicator variables; (5)

\footnotetext{
7 The models were estimated using "number of occasions of marijuana use in past 30 days" and "number of occasions of cocaine use in lifetime" instead of these dummy indicators of drug use. The results were qualitatively similar to those presented here.
} 
mother's and father's education levels (high school graduate as the baseline, high school dropout, some college, college graduate); (6) family structure in $8^{\text {th }}$ grade (two parents as the baseline, step-family, single parent); (7) family income quartiles; (8) number of siblings; and (9) whether or not the school is located in a suburban (baseline), rural or urban area. This information was collected in 1988 as part of the baseline student and school surveys.

In order to control for concurrent factors that may confound an observed empirical relationship between substance use and educational attainment, some models include a set of personal and school characteristics measured in the current grade $\left(10^{\text {th }}\right.$ or $12^{\text {th }}$ grade). These variables are: (1) whether or not the standardized percentile score on math achievement test is in the lowest quartile8; (2) a dummy variable indicating daily smoking; (3) a dummy variable indicating that the principal thinks drugs are a moderate to serious problem at this school; and (4) a dummy variable indicating that the school policy is to expel students for a first occurrence of illegal drug possession at school. The math test is part of the NELS survey, and students selfreported the information about smoking. The school principal, or a similar administrator, reported information about the drug environment at school and the school's policy regarding drug possession at school. No information is available on enforcement of school policy.

To control for drug use in the student's peer group in high school, the models also include whether or not the student reports that s/he has been offered to buy drugs at school. This is not an ideal measure of drug use among the student's peers, since drug offers will also be influenced by state and school-level policies, and community-level factors. However, if a student associates with drug-using peers, one would expect that s/he would be more likely to be offered drugs at school compared to a student who does not associate with drug-using peers. 
A set of $8^{\text {th }}$ grade personal characteristics are added to the model to control for preexisting differences between youth that may affect both high school substance use and educational attainment. These measures are: (1) whether or not the respondent was a daily smoker in $8^{\text {th }}$ grade; (2) math test score in $8^{\text {th }}$ grade was in lowest quartile; (3) whether or not the student had repeated a grade by $8^{\text {th }}$ grade; and (4) the number of times since the $8^{\text {th }}$ grade school year began that the student's parent was contacted by the school about the student's behavior in school. To control for drug use in the $8^{\text {th }}$ grade peer group, the models also include a self-report of whether or not the student was offered to buy drugs in $8^{\text {th }}$ grade. The math test was administered to the respondents as part of the survey, and students self-reported repeating a grade, drug offers, and smoking behavior. The parent reported the number of times he or she was contacted by the school as part of the parent survey

Four state-level substance use policies and prices are included in the models as identifying variables. These variables are meant to proxy the full price that adolescents face when using marijuana and cocaine. The variables are: (1) the midpoint of the minimum and maximum jail terms for marijuana possession in the state; (2) the midpoint of the minimum and maximum fine for marijuana possession in the state; (3) whether or not the state has decriminalized marijuana; and (3) the real money price of cocaine. The jail terms and fines for marijuana possession pertain to a first offence of possessing the lowest quantity of marijuana mentioned in the statute (see Pacula et al. 2003b). The methodology for creating the cocaine price series is described in detail in Grossman and Chaloupka (1998). The following statelevel variables are used in some specifications to proxy state sentiment: (1) unemployment rate; (2) average real income; and (3) percentage of state that is Southern Baptist, Catholic,

\footnotetext{
${ }^{8}$ Psychologists have found that while there is not necessarily a negative correlation between intelligence and drug use (in fact, the opposite may be true), school failure predicts drug use. The use of lowest quartile math score is
} 
Mormon and Protestant as of 1990. Data on religion comes from Bradley et al. (1992).

Finally, school-level variables measured in $8^{\text {th }}$ grade are used for identification in some IV models. These variables, intended to capture the availability of drugs in $8^{\text {th }}$ grade, are the following: (1) dummy variable indicating that the principal thinks drugs are a moderate to serious problem at this school; and (2) dummy variable indicating that the school policy is to expel students for a first occurrence of illegal drug possession at school. These variables are used for identification while controlling for the same two variables measured in high school. The school information was obtained from the school administrator survey.

\section{$4 \quad$ Results}

\subsection{Do students select into high school substance use based on problem behaviors in $8^{\text {th }}$ grade?}

Table 1 presents sample means. The average number of years of education completed by 2000 was about 14 years in both samples. Among $10^{\text {th }}$ grade students, about 6 percent had used marijuana in the past month, and about 3 percent reported any lifetime cocaine use. In the $12^{\text {th }}$ grade sample, 9 percent of students reported past month marijuana use and 4 percent reported lifetime cocaine use. The rates for the $12^{\text {th }}$ grade sample in 1992 are somewhat lower than illicit drug use rates among 1992 seniors from Monitoring the Future (MTF), a yearly national survey of high school students' substance use. In the MTF, 12 percent of respondents used marijuana in the past month, and 6 percent of respondents reported lifetime cocaine use.

As other studies have documented, high school students in both samples select into drug use based on certain family and personal characteristics that are likely to influence educational attainment (Table 2). In the $10^{\text {th }}$ grade sample, family and personal risk factors for illicit drug use include smoking, alcohol use, having a parent who is a high school dropout, living in a single 
parent family, having a low math score in high school, and having been offered drugs at school (which is included to proxy drug-using peer group). Protective factors include having a parent who is a college graduate, African-American or Asian race/ethnicity, attending a rural school, and living in the South. Most studies of illicit drug use and educational attainment have included controls for these factors in their regression models.

It is striking to see the differences in $8^{\text {th }}$ grade problem behaviors between high school drug users and non-users. For example, 19 percent of $10^{\text {th }}$ grade marijuana users report smoking in $8^{\text {th }}$ grade, compared to just 3 percent of non-users. As the data in Table 2 demonstrate, high school marijuana users are much more likely than non-users to enter high school with educational risk factors, such as low math scores, behavior problems and associating with a deviant peer group. This selection into drug use along preexisting, educational risk factors is more evident for cocaine use than for marijuana use. Previous studies have not included these important correlates of high school drug use because they lacked data on student characteristics measured before high school entrance.

\subsection{OLS Estimates: Using observed data to assess selection along family characteristics, student characteristics measured in high school, and student characteristics measured before high school entrance}

Table 3 shows results from OLS models that estimate the association between illicit drug use and educational attainment. The first two rows summarize models that include $10^{\text {th }}$ and $12^{\text {th }}$ grade marijuana use measures, while the second two rows summarize models that include $10^{\text {th }}$ and $12^{\text {th }}$ grade cocaine use measures. Column (1) in each table shows the estimated coefficient on illicit drug use from a model without any controls. The following columns (2-5) show increasingly richer specifications in order to gauge the degree of selection on observed characteristics. Column 2 shows results from a model that includes a basic set of demographic 
and family characteristics. Column 3 displays results from a model that also includes school and personal variables measured in high school. Finally, Column 4 shows results from a model that also captures $8^{\text {th }}$ grade problem behaviors, and Column 5 displays results from a model that includes alcohol and illicit drug measures simultaneously.

As a group, these models show evidence of a robust, negative association between illicit drug use and educational attainment. In almost every model, high school marijuana and cocaine use is associated with a statistically significant reduction of 0.1 to 1.3 in the number of years of schooling completed by age 26 . However, a significant portion of this association can be explained by selection into drug use along family and personal characteristics. For example, in a model without any controls, marijuana use in $10^{\text {th }}$ grade is associated with almost a full year reduction in educational attainment (Table 2, Column 1). After including a basic set of demographic and family controls, this effect diminishes in magnitude to -0.74 , a 22 percent reduction. When a set of high school student and school characteristics is added to the model, the estimated coefficient on marijuana use declines in magnitude to -0.228 , which is a reduction of almost 70 percent. As seen in the other rows of Table 3, this trend is apparent in models that include measures of $12^{\text {th }}$ grade marijuana use, $10^{\text {th }}$ grade cocaine use, and $12^{\text {th }}$ grade cocaine use.

Column 4 in Table 2 shows results from a model which includes all of the covariates included in previous models but also accounts for risk factors for substance use that were measured before high school entrance. Including $8^{\text {th }}$ grade measures does reduce the estimated association between illicit drug use and educational attainment in every case. The size of this reduction is 16 to 28 percent for the $10^{\text {th }}$ grade measures, indicating considerable levels of selection into $10^{\text {th }}$ grade drug use along $8^{\text {th }}$ grade problem behaviors. On the other hand, the findings suggest that selection into $12^{\text {th }}$ grade substance use along $8^{\text {th }}$ grade risk factors is not as 
important. The magnitudes of the coefficients on $12^{\text {th }}$ grade substance use decline by about 6 percent when the $8^{\text {th }}$ grade characteristics are added to the model.

To summarize, the negative, statistically significant association between substance use and educational attainment persists even when $8^{\text {th }}$ grade risk factors are included in the model. If the most important determinants of drug use and educational attainment are measurable in NELS, this finding supports the idea that this relationship is causal. The OLS findings also suggest that selection into drug use and educational attainment along preexisting factors is more important for $10^{\text {th }}$ grade substance use than for $12^{\text {th }}$ grade substance use.

\subsection{Estimates: Addressing the Potentially Endogenous Drug Use Measures}

The results displayed in Table 3 do not directly address the possibility that some of the important determinants of drug use and educational attainment may be left out of the model. Table 4 and Table 5 show results from IV models. The IV models purge the potentially endogenous drug use measure of its correlation with the error term. If the IV estimates support the OLS findings, one can make a stronger case for a causal relationship between illicit drug use and educational attainment.

Table 4 focuses on the effects of $10^{\text {th }}$ grade substance use on educational attainment. Columns (1-2) show results from IV models that include only the basic set of covariates, which are thought to be exogenous from the respondent's perspective. Columns (3-6) show results from IV models that include the full set of covariates, which includes the basic set along with the high school student and school characteristics and the $8^{\text {th }}$ grade risk factors. Because some of these variables are likely to be endogenous, these results should be interpreted with caution.

Table 4 displays for each model the results from an over-identification test, a Hausman specification test, and an F-test on the identifying instruments. These test results allow one to 
gauge the validity of the identifying instruments, as well as the effects of endogeneity on the consistency of the estimates, in every model. Also, Table 4 shows results from models with and without state sentiment variables included, and with all of the state-level and school-level identifying instruments included together as well as separately by group. This approach allows an examination of whether or not the results are sensitive to the instruments used to identify the model.

Panel A in Table 4 shows all IV results for $10^{\text {th }}$ grade marijuana use. Two findings are notable. First, in the fully specified IV model (Table 4, Panel A, Column 3) the estimated coefficient on marijuana use is -0.161 , which is reasonably close to the corresponding OLS estimate of -0.192 (Table 3, Column 4). The IV estimate, however, is not statistically significant. Second, there is no evidence in any of the models that endogeneity affects the consistency of the estimates, and the instruments appear to be validly excluded from the educational attainment equation in every case. The addition of variables to proxy state sentiment generally does not change the signs of the estimates, but the magnitudes of the estimates do change in some cases when these variables are included. This finding is consistent with the idea that state sentiments are correlated with drug policies and educational attainment. The predictive power of the full set of identifying instruments ranges from modest (in the models with exogenous covariates only) to reasonable (in the fully specified models).

Panel B in Table 4 shows all IV results for $10^{\text {th }}$ grade cocaine use. These results are not consistent with the OLS results for $10^{\text {th }}$ grade cocaine use. The estimated coefficient on cocaine use is large and positive in 5 of the 6 models estimated. The predictive power of the instruments is reasonable in most of these models, and there is no evidence that the identifying instruments should be included in the educational attainment equation. 
Table 5 shows results from IV models that focus on $12^{\text {th }}$ grade substance use. These effects capture the impact of drug use on post-secondary educational attainment. Panel C displays results from marijuana use models, while Panel D shows results from cocaine use models. As seen in Panel C, the IV results do not support the idea that marijuana use in $12^{\text {th }}$ grade reduces educational attainment in the future. All of the estimates are positive in sign, regardless of model specification, whether or not state sentiment variables are included, and which set of instruments is used. These estimates suggest that marijuana use in $12^{\text {th }}$ grade does not affect post-secondary educational attainment.

The $12^{\text {th }}$ grade cocaine use models, however, are consistent with the OLS results (Table 5, Panel C). When only the exogenous covariates are included in the model, cocaine use has a negative, statistically insignificant association with educational attainment. The size of the coefficient is -0.997 in the fully specified model (Table 5, Panel D, Column 3), which is considerably larger in magnitude to the estimate of -0.381 from the corresponding OLS model (Table 3, Column 4). When the more extensive set of covariates is included, the signs of the estimated coefficients remain negative in most cases, but the instruments perform poorly in terms of predictive power. In the fully specified model with state sentiment included (Table 5, Panel D, Column 4), the sign on the cocaine use coefficient becomes positive. The Durbin-WuHausman test is used to test every model to see whether or not the endogeneity of the drug use measure with respect to education affects the consistency of the estimated coefficient. There is no evidence of this problem in these models.

The Appendix Table displays the estimated coefficients on marijuana fine, marijuana jail term, marijuana decriminalization, and cocaine price from the first stage drug use equations. These results offer interesting information about the effects of illicit drug policies and prices on 
adolescent drug use. In every case, higher marijuana fines are associated with statistically significant declines in the probability of past month marijuana use. Pacula et al. find a negative but statistically insignificant association between marijuana fines and marijuana use using NELS data. Higher marijuana fines are also associated with higher probability of cocaine use among $10^{\text {th }}$ grade students, which implies substitution between cocaine and marijuana. Marijuana decriminalization is associated with increases in marijuana use among $12^{\text {th }}$ grade students, and decreases in cocaine use among $10^{\text {th }}$ grade students.

Overall, then, the results presented in Table 4 and Table 5 support the OLS results in the cases of $10^{\text {th }}$ grade marijuana use and $12^{\text {th }}$ grade cocaine use, but with some important caveats. First, none of the IV results are statistically significant, which often occurs in IV estimation with relatively weak instruments. Second, the IV estimates are sensitive to both model specification and to the set of identifying instruments used. For example, the negative association between $10^{\text {th }}$ grade marijuana use and educational attainment disappears when only a basic set of covariates is included in the model (Table 4, Panel A, Columns 1-2), or when only state-level policies are used to identify the educational attainment equation (Table 4, Panel A, Column 5). ${ }^{9}$ However, given the fact that the Hausman test does not suggest that endogeneity of the drug use measure affects the consistency of the estimates in any of the models, the OLS estimates may be the preferred estimates in this analysis.

\section{Conclusions}

Previous research has highlighted the strong association between teenage substance use and reduced educational attainment, but it is not clear whether or not the relationship is causal. These findings suggest that it is likely that past month marijuana use in $10^{\text {th }}$ grade and lifetime

\footnotetext{
${ }^{9}$ In certain cases, the IV results are also sensitive to whether or not the marijuana decriminalization indicator is used as an identifying variable. These results are not presented here.
} 
cocaine use by $12^{\text {th }}$ grade may detract from educational attainment. The magnitudes of these effects may be considerable. For example, in the most fully specified OLS model (see Table 3, column (4)), marijuana use in $10^{\text {th }}$ grade has a similar impact on educational attainment $(-0.192)$ as living in a single parent family (-0.194), or living in a family with an income in the lowest quartile (-0.278). ${ }^{10}$ If these effects are causal, targeting illicit drug $u s e$ with an effective treatment or prevention program may be an efficient way to improve educational attainment. If these effects are not causal, targeting illicit drug users still may be an effective way to improve educational attainment, but it is less clear that a drug treatment or prevention program alone will improve their educational outcomes.

The results regarding the effect of marijuana use on high school outcomes are consistent in sign with the two previous studies on this topic in the health economics literature. Yamada et al. and Bray et al., find that marijuana users are more likely to drop out of high school than nonusers. Bray et al. use data from a single school system rather than national data, and Yamada et al. do not test for endogeneity problems or show results that take into account the problem of endogeneity. Neither study considers post-secondary outcomes. These issues make it difficult to compare their results to the findings presented here. However, the OLS estimates in this paper appear to be smaller than these estimates since it is unlikely that a decrease of about a fifth of a year of schooling would affect high school graduation. The results in this paper also are consistent with recent work by Pacula et al. (2003a), who use NELS and show that marijuana use is associated with a $15 \%$ reduction in math achievement test scores.

This research supports the idea that public policies that are effective in reducing substance use during high school should have some impact on educational attainment. It is

\footnotetext{
${ }^{10}$ Living in a single parent family is compared to the baseline of living with both biological parents. Living in a
} family in the lowest income quartile is compared a to a family with income in the second highest quartile. 
important to note that the effects of these policies on educational attainment may take years to be realized. Substance use during high school may not immediately affect educational outcomes preventing use in $12^{\text {th }}$ grade, therefore, may not affect high school graduation. However, this paper suggests that using marijuana and cocaine can alter students' long-term educational trajectories. Future research should focus on understanding what processes lead substance using adolescents to low educational attainment, and what policies can do to alter these pathways. 


\section{References}

Bachman JG, Wallace JM, O'Malley PM, Johnston LD, Kurth CL, Neighbors HW. Racical/ethnic differences in smoking, drinking and illicit drug use among American high school seniors, 1976-89. American Journal of Public Health 1991; 81: 372-377.

Bollen KA, Guilkey DK, Mroz TA. Binary outcomes and endogenous explanatory variables: tests and solutions with an application to the demand for contraceptive use in Tunisia. Demography. 1995;32:111-131.

Bound J, Jaeger DA, Baker RM. Problems with instrumental variables estimation when the correlation between the instruments and the endogenous explanatory variables is weak. Journal of the American Statistical Association. 1995;90:443-450.

Bradley, M. R., Green Jr., N.M., Jones, D. E., Lynn, M. and McNeil, L. Churches and Church Membership in the United States 1990, Atlanta: Glenmary Research Center, 1992.

Brandon RN. Impact of peer substance use on middle school performance in Washington. Interim Repprt to the Division of Alcohol and Substance Abuse, Department of Social and Health Services, State of Washington, September 12, 2000.

Bray J, Zarkin G, Ringwalt C, Qi J. The relationship between marijuana initiation and dropping out of high school. Health Economics 2000; 9: 9-18.

Brook JS, Balka EB, Whiteman M. The risks for late adolescence of early marijuana use. American Journal of Public Health 1999; 89: 1549-1554.

Byrant AL, Schulenberg JE, O'Malley PM, Bachman JG, Johnston LD. How academic achievement, attitudes and behaviors relate to the course of substance use during adolescence: A six year multi-wave longitudinal study. Journal of Research on Adolescence 2003; 13: 361-397.

Cook P, Moore M.. Drinking and schooling. Journal of Health Economics 1993; 12: 411-429.

Dee T. State alcohol policies, teen drinking and traffic fatalities. Journal of Public Economics 1999; 72: 289-315.

Dee TS, Evans WN. Teen drinking and educational attainment: evidence from two-sample instrumental variables (TSIV) estimates. The Journal of Labor Economics.

2003; $21: 178-209$.

DeSimone J. Illegal drug use and employment. Journal of Labor Economics 2002; 20: 952-977.

DeWit DJ. Frequent childhood geographic relocation: Its impact on drug use initiation and the development of alcohol and other drug-related problems among adolescents and young adults. Addictive Behaviors 1998; 23: 623-634. 
Diego MA, Field TM, Sander CE. Academic performance, popularity, and depression predict adolescent substance use. Adolescence 2003; 38.

Field T, Diego M, Sanders C. Adolescent depression and risk factors. Adolescence 2001; 36: 491-498.

Flewelling RL, Bauman KE. Family structure as a predictor of initial substance use and sexual intercourse in early adolescence. Journal of Marriage and the Family 1990; 52: 171-81.

Greene WH. Econometric Analysis, Fifth Edition. Pearson Education Inc., Upper Saddle River NJ: 2003.

Griffin KW, Botvin GJ, Scheier LM, Nichols TR. Factors associated with regular marijuana use among high school students: A long-term follow-up study. Substance use and misuse 2002; 37: 225-238.

Grossman, M., Chaloupka, F.J., 1998. The demand for cocaine by young adults: A rational addiction approach. Journal of Health Economics, 17, 427-474.

Hawkins JD, Catalano RF, Miller JY. Risk and protective factors for alcohol and other drug problems in adolescence and early adulthood: Implications for substance use prevention. Psychological Bulletin 1992; 112: 64-105.

Jessor R, Jessor SL. Problem Behavior and Psychosocial Development: A Longitudinal Study of Youth. Academic Press, New York: 1977.

Jeynes WH. The effects of recent parental divorce on their children's consumption of marijuana and cocaine. Journal of Divorce \& Remarriage 2001; 35: 43-65.

Johnston LD, O'Malley PM, Bachman JG. (December 16, 2002). Ecstasy use among American teens drops for the first time in recent years, and overall drug and alcohol use also decline in the year after 9/11. University of Michigan News and Information Services: Ann Arbor, MI. [Online]. Available: www.monitoringthefuture.org; accessed 9/30/03.

Kaestner R. The effect of illicit drug use on the wages of young adults. Journal of Labor Economics 1991; 9: 381-412.

Kaestner R. New estimates of the effect of marijuana and cocaine use on wages. Industrial and Labor Relations Review 1994; 454-470.

Koch SF, Ribar DC. A siblings analysis of the effects of alcohol consumption onset on educational attainment. Contemporary Economic Policy. 2001;19:162-74.

Kandel D. Stages in adolescent involvement in drug use. Science 1975; 190: 912-914. 
Kandel D, Davies M. Labor force experiences of a national sample of young adult men: The rold of drug involvement. Youth \& Society 1990; 21: 411-445.

Molina BS, Pelham WE. Childhood predictors of adolescent substance use in a longitudinal study of children with ADHD. Journal of Abnormal Psychology 2003; 112: 497-507.

Moral AR, McCaffrey DF, Paddock SM. Reassessing the marijuana gateway effect. Addiction 2002; 97: 1493-1504.

Office of National Drug Control Policy (ONDCP), America's Drug Use Profile, Youth Drug Use, a Problem with Profound

Implications. http://www.ncjrs.org/ondcppubs/publications/policy/99ndes/ii-c.html, Accessed 9/23/03.

Pacula RL, Ringel J, Ross KE. Does marijuana use impair human capital formation? National Bureau of Economic Research Working Paper 9963, September 2003a.

Pacula RL, Chriqui JF, King J. Marijuana decriminalization: what does it mean in the United States? National Bureau of Economic Research Working Paper 9690, May 2003 b.

Painter G, Levine DI. Family structure and youths' outcomes: which correlations are causal? The Journal of Human Resources 2000; 3: 524-549.

National Center for Education Statistics (NCES), NELS base-year to fourth follow-up data file user's manual, June 2002.

Nelson CR, Startz R. The distribution of the instrumental variables estimator and its T-Statistic when the instrument is a poor one. Journal of Business. 1990;63:S125-S139.

Newcomb M, Bentler P. The impact of high school substance use on choice of young adult living environment and career direction. Journal of Drug Education 1985; 15: 253-260.

Newcomb M, Bentler P. Drug use, educational aspirations, and work force involvement: The transition from adolescence to young adulthood. American Journal of Community Psychology 14; 1986: 303-321.

Newcomb M, Bentler P. Consequences of Adolescent Drug Use, Sage Publications 1988. Staiger D, Stock JH. Instrumental variables regression with weak instruments. Econometrica. 1997; 65: 557-86.

Sale E, Sambrano S, Springer JF, Turner CW. Risk, protection, and substance use in adolescents: A multi-site model. Journal of Drug Education 2003; 33: 91-105.

Slater MD. Sensation-seeking as a moderator of the effects of peer influences, consistency with personal aspirations and perceived harm on marijuana and cigarette use among younger adolescents. Substance use and misuse 2003; 38: 865-880. 
U.S. Department of Justice. Substance abuse: The nation's number one health problem. Office of Juvenile Justice and Delinquency Prevention Fact Sheet \#17, May 2001.

Yamada T, Kendix M, Yamada T. The impact of alcohol and marijuana consumption on high school graduation. Health Economics, 1998. 
Table 1: Sample Means and Standard Deviations

Variable

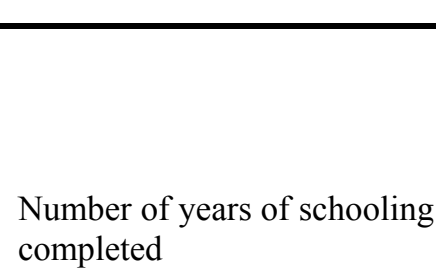

Smokes daily

Used alcohol in past 30 days

Used marijuana in past 30 days

Used cocaine in lifetime
Definition

Number of years of education completed in 2000, when most respondents are about 26 years old

Dummy variable $=1$ if respondent reports daily smoking, 0 otherwise

Dummy variable $=1$ if respondent reports use of alcohol in the past 30 days, 0 otherwise

Dummy variable $=1$ if respondent reports use of marijuana in past 30 days, 0 otherwise
Mean

(standard deviation)

$10^{\text {th }}$ grade

sample

$(\mathrm{N}=6,231)$

13.93

0.156

0.395

0.516

2 grade sample

$(\mathrm{N}=4,088)$

14.18
0.060

0.028

0.035 reports use of cocaine in lifetime, 0 otherwise

\section{Demographic Characteristics}

Female

Dummy variable $=1$ if respondent is

0.545

0.549 female, 0 otherwise

African-American

Dummy variable $=1$ if respondent

0.076

0.068

is African-American, 0 otherwise

Hispanic

Dummy variable $=1$ if respondent is

0.093

0.077 Hispanic, 0 otherwise

Asian

Dummy variable $=1$ if respondent is

0.067

0.065

$$
\text { Asian, } 0 \text { otherwise }
$$

Native American

Dummy variable $=1$ if respondent is

0.036

Native American, 0 otherwise

Central

Dummy variable $=1$ if respondent

0.318

0.336

lives in Central region, 0 otherwise

West

Dummy variable $=1$ if respondent

South lives in West region, 0 otherwise

0.326

0.319 


\begin{tabular}{|c|c|c|c|}
\hline Urban & $\begin{array}{l}\text { Dummy variable }=1 \text { if respondent } \\
\text { lives in urban area, } 0 \text { otherwise }\end{array}$ & 0.248 & 0.233 \\
\hline Rural & $\begin{array}{l}\text { Dummy variable }=1 \text { if respondent } \\
\text { lives in rural area, } 0 \text { otherwise }\end{array}$ & 0.336 & 0.356 \\
\hline Catholic & $\begin{array}{c}\text { Dummy variable }=1 \text { if respondent is } \\
\text { Catholic, } 0 \text { otherwise }\end{array}$ & 0.283 & 0.305 \\
\hline \multicolumn{4}{|l|}{ Baptist or Methodist } \\
\hline & $\begin{array}{l}\text { Dummy variable }=1 \text { if respondent is } \\
\text { Baptist or Methodist, } 0 \text { otherwise }\end{array}$ & 0.272 & 0.265 \\
\hline \multicolumn{4}{|l|}{ Other Christian } \\
\hline & $\begin{array}{c}\text { Dummy variable }=1 \text { if respondent is } \\
\text { of other Christian denomination } \\
\qquad, 0 \text { otherwise }\end{array}$ & 0.283 & 0.284 \\
\hline \multicolumn{4}{|l|}{ Other Religion } \\
\hline & $\begin{array}{l}\text { Dummy variable }=1 \text { if respondent is } \\
\text { of another religion, } 0 \text { otherwise }\end{array}$ & 0.078 & 0.074 \\
\hline \multicolumn{4}{|c|}{ Family Characteristics } \\
\hline \multicolumn{4}{|l|}{ Mother dropout } \\
\hline & $\begin{array}{c}\text { Dummy variable }=1 \text { if respondent's } \\
\text { mother is a high school dropout, } 0 \\
\text { otherwise }\end{array}$ & 0.216 & 0.195 \\
\hline \multicolumn{4}{|l|}{ Mother college graduate } \\
\hline & $\begin{array}{c}\text { Dummy variable }=1 \text { if respondent's } \\
\text { mother is a college graduate, } 0 \\
\text { otherwise }\end{array}$ & 0.249 & 0.257 \\
\hline Mother some college & $\begin{array}{l}\text { Dummy variable }=1 \text { if respondent's } \\
\text { mother completed some college but } \\
\text { did not graduate, } 0 \text { otherwise }\end{array}$ & 0.199 & 0.213 \\
\hline \multicolumn{4}{|l|}{ Father dropout } \\
\hline & $\begin{array}{c}\text { Dummy variable }=1 \text { if respondent's } \\
\text { father is a high school dropout, } 0 \\
\text { otherwise }\end{array}$ & 0.241 & 0.214 \\
\hline Father some college & $\begin{array}{l}\text { Dummy variable }=1 \text { if respondent's } \\
\text { father completed some college but } \\
\text { did not graduate, } 0 \text { otherwise }\end{array}$ & 0.174 & 0.187 \\
\hline Father college graduate & $\begin{array}{c}\text { Dummy variable }=1 \text { if respondent's } \\
\text { father is a college graduate, } 0 \\
\text { otherwise }\end{array}$ & 0.303 & 0.318 \\
\hline Single parent family & $\begin{array}{l}\text { Dummy variable }=1 \text { if respondent } \\
\text { lives with one biological parent or } \\
\text { relative only, } 0 \text { otherwise }\end{array}$ & 0.162 & 0.143 \\
\hline Step-family & $\begin{array}{c}\text { Dummy variable }=1 \text { if respondent } \\
\text { lives with one biological parent and } \\
\text { another non-biological parent figure, } \\
0 \text { otherwise }\end{array}$ & 0.108 & 0.101 \\
\hline Family income & Family income measured in $8^{\text {th }}$ grade & $\begin{array}{c}42,978 \\
(36,421)\end{array}$ & $\begin{array}{c}44,660 \\
(37,137)\end{array}$ \\
\hline
\end{tabular}




\begin{tabular}{lccc}
\hline Number of siblings & Number of siblings & 2.14 & 2.10 \\
& & $(1.49)$ & $(1.47)$ \\
& & \\
\hline
\end{tabular}

Low math score

Dummy variable $=1$ if standardized

0.250

0.260

achievement test score in

mathematics is in lowest quartile, 0

otherwise

Was offered drugs

Dummy variable $=1$ if respondent

0.149

0.130

reports that someone offered to sell

$\mathrm{him} / \mathrm{her}$ drugs at school during first

semester of $10^{\text {th }}$ grade school year, 0

otherwise

Punishment for drug possession is expulsion

Dummy variable $=1$ if school

0.372

0.376

administrator reports that the punishment for first occurrence of illegal drug possession is expulsion from school, 0 otherwise

Drugs are a problem at this school

Dummy variable $=1$ if school

0.240 administrator reports that student use of illegal drugs is a moderate or severe problem at this school, 0 otherwise

$8^{\text {th }}$ grade personal characteristics

Repeated a grade

Low math score in $8^{\text {th }}$ grade

Smoked daily in $8^{\text {th }}$ grade

Number of times school called parents about behavior
Dummy variable $=1$ if respondent reports that $\mathrm{s} / \mathrm{he}$ repeated a grade before $8^{\text {th }}$ grade, 0 otherwise

Dummy variable $=1$ if standardized achievement test score in mathematics in $8^{\text {th }}$ grade is in lowest quartile, 0 otherwise

Dummy variable $=1$ if respondent smoked daily in $8^{\text {th }}$ grade, 0 otherwise

Number of times since school year began parent was contacted by school about respondent's behavior in school, as reported by parent
0.105

0.235

0.042

1.32

(0.648)

(0.618) 


\begin{tabular}{|c|c|c|c|}
\hline Was offered drugs in $8^{\text {th }}$ grade & $\begin{array}{c}\text { Dummy variable }=1 \text { if respondent } \\
\text { reports that someone offered to sell } \\
\text { him/her drugs at school during first } \\
\text { semester of current school year, } 0 \\
\text { otherwise } \\
8^{\text {th }} \text { grade school characteristics }\end{array}$ & 0.076 & 0.069 \\
\hline $\begin{array}{l}\text { Punishment for drug possession is } \\
\text { expulsion in } 8^{\text {th }} \text { grade }\end{array}$ & $\begin{array}{l}\text { Dummy variable }=1 \text { if school } \\
\text { administrator reports that the } \\
\text { punishment for first occurrence of } \\
\text { illegal drug possession is expulsion } \\
\text { from school, } 0 \text { otherwise }\end{array}$ & 0.251 & 0.255 \\
\hline $\begin{array}{l}\text { Drugs are a problem at this school in } \\
8^{\text {th }} \text { grade }\end{array}$ & $\begin{array}{l}\text { Dummy variable }=1 \text { if school } \\
\text { administrator reports that student use } \\
\text { of illegal drugs is a moderate or } \\
\text { severe problem at this school, } 0 \\
\text { otherwise }\end{array}$ & 0.085 & 0.076 \\
\hline \multicolumn{4}{|c|}{ State Illicit Drug Prices } \\
\hline State marijuana fine & $\begin{array}{c}\text { Midpoint of minimum and } \\
\text { maximum fine for marijuana } \\
\text { possession, 1st weight category, in } \\
\text { dollars }\end{array}$ & $\begin{array}{l}0.658 \\
(4.25)\end{array}$ & $\begin{array}{l}0.633 \\
(4.01)\end{array}$ \\
\hline State marijuana jail term & $\begin{array}{l}\text { Midpoint of minimum and } \\
\text { maximum jail term for marijuana } \\
\text { possession, } 1^{\text {st }} \text { weight category, in }\end{array}$ & 0.227 & 0.223 \\
\hline Marijuana decriminalization & $\begin{array}{l}\text { Dummy variable }=1 \text { if state has } \\
\text { decriminalized marijuana }\end{array}$ & 0.289 & 0.271 \\
\hline State Cocaine price & $\begin{array}{l}\text { Predicted price of a gram of pure } \\
\text { cocaine using a model that assumes } \\
\text { potency to be endogenous and } \\
\text { restricts the coefficient of potency } \\
\text { and net weight to be the same in the } \\
\text { second stage of the regression. } \\
\text { State Sentiment Variables }\end{array}$ & $\begin{array}{l}135.46 \\
(29.85)\end{array}$ & $\begin{array}{r}98.63 \\
(25.18)\end{array}$ \\
\hline Protestant & $\%$ of state that is Protestant & 23.40 & 23.96 \\
\hline Southern Baptist & $\%$ of state that is Southern Baptist & 7.12 & 7.02 \\
\hline Catholic & $\%$ of state that is Catholic & 20.47 & 20.72 \\
\hline Mormon & $\%$ of state that is Mormon & 1.23 & 1.14 \\
\hline Income & Real per capita income in dollars & 19,110 & 20,501 \\
\hline Unemployment & State unemployment rate & 5.51 & 7.21 \\
\hline
\end{tabular}


Table 2: Selection Into Drug Use Along Observed Characteristics

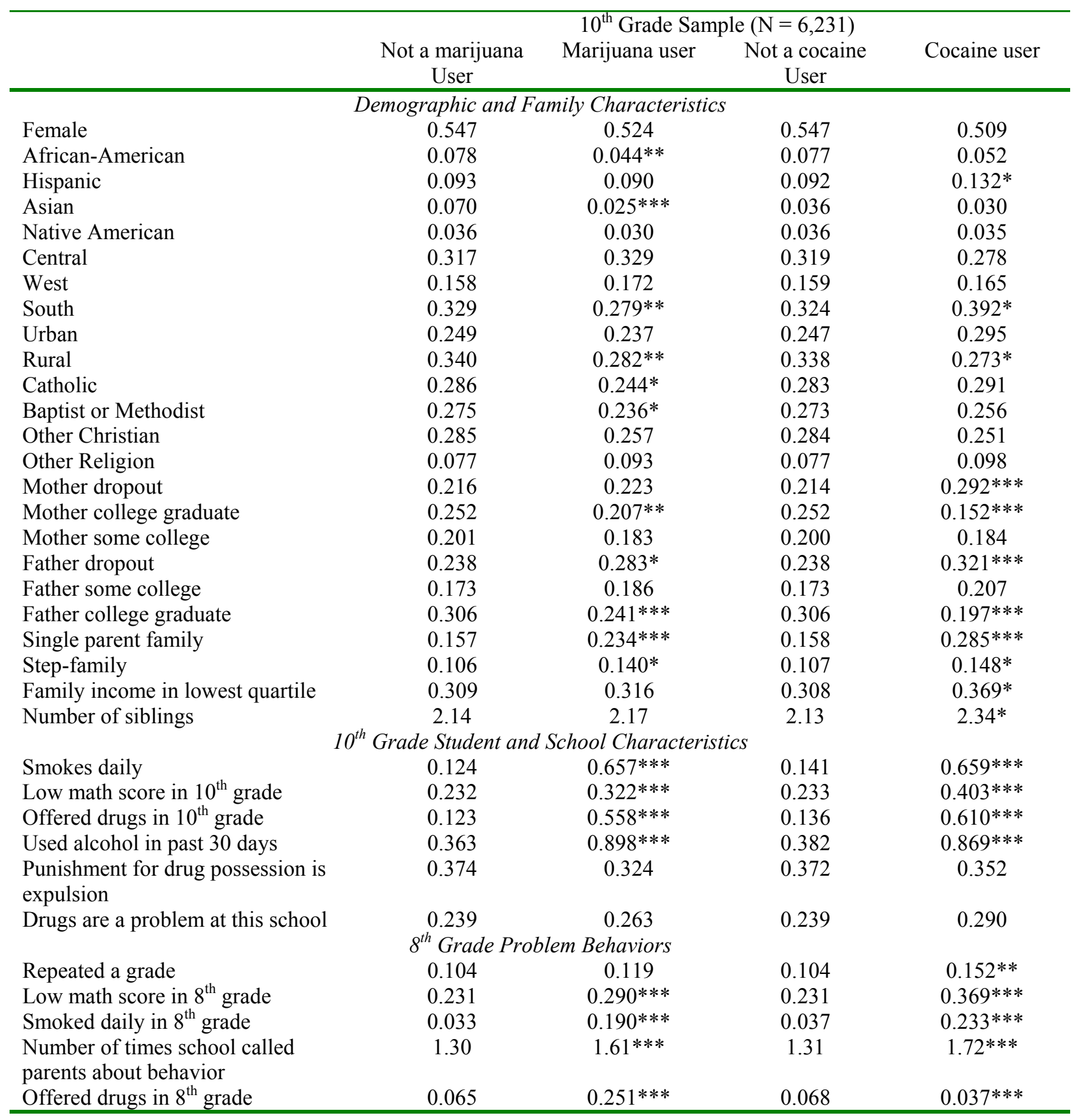




\begin{tabular}{|l|ccccc|}
\hline \multicolumn{5}{|c|}{ Table 3: Illicit Drug Use and Educational Attainment } \\
OLS estimate \\
(T-Statistic)
\end{tabular}

1) Huber-White standard errors with adjustment for clustering on state of residence.

2) Column (2) basic controls: female, race/ethnicity categories, region categories, urban, rural, religion categories, mother dropout, mother some college, mother college graduate, father dropout, father some college, father college graduate, single parent family, stepfamily, income quartile categories, number of siblings.

3) Column (3) high school variables: low $10^{\text {th }}$ grade math score, smokes daily in $10^{\text {th }}$ grade, drugs are a problem at this school, offered drugs in $10^{\text {th }}$ grade, punishment for drug possession is expulsion.

4) Column (4) $8^{\text {th }}$ grade personal variables: repeated a grade, low $8^{\text {th }}$ grade math score, smoked daily in $8^{\text {th }}$ grade, number of times parents were called for behavior problems in $8^{\text {th }}$ grade, drug offer in $8^{\text {th }}$ grade.

5) Column (5) all substance use variables: any past month alcohol use, past month marijuana use, lifetime cocaine use (all measured in current grade). 


\begin{tabular}{|c|c|c|c|c|c|c|}
\hline \multicolumn{7}{|c|}{$\begin{array}{l}\text { Table 4: Effects of } \mathbf{1 0}^{\text {th }} \text { Grade Drug Use on Educational Attainment } \\
\text { Instrumental Variables Estimate } \\
\text { (T-Statistic) }\end{array}$} \\
\hline & \multicolumn{6}{|c|}{ Number of Years of Education } \\
\hline & \multicolumn{2}{|c|}{ Exogenous covariates only } & \multicolumn{4}{|c|}{ Full set of covariates } \\
\hline & (1) & (2) & (3) & (4) & (5) & (6) \\
\hline & $\begin{array}{l}\text { IV w/ } \\
\text { full set of } \\
\text { instruments }\end{array}$ & $\begin{array}{l}\text { Model (1) } \\
\text { w/state } \\
\text { sentiment } \\
\text { variables }\end{array}$ & $\begin{array}{l}\text { IV w/ } \\
\text { full set of } \\
\text { instruments }\end{array}$ & $\begin{array}{l}\text { Model (3) } \\
\text { w/state } \\
\text { sentiment } \\
\text { variables }\end{array}$ & $\begin{array}{l}\text { IV w/state } \\
\text { policies } \\
\text { only as } \\
\text { instruments }\end{array}$ & $\begin{array}{l}\text { IV w/school } \\
\text { policies only as } \\
\text { instruments }\end{array}$ \\
\hline \multicolumn{7}{|l|}{ PANEL A } \\
\hline $\begin{array}{l}\text { Marijuana use in } 10^{\text {th }} \\
\text { grade }\end{array}$ & $\begin{array}{r}0.547 \\
(0.200\end{array}$ & $\begin{array}{c}0.824 \\
(0.280)\end{array}$ & $\begin{array}{c}-0.161 \\
(-0.090)\end{array}$ & $\begin{array}{c}-0.146 \\
(-0.080)\end{array}$ & $\begin{array}{c}0.416 \\
(0.893)\end{array}$ & $\begin{array}{l}-0.458 \\
(-0.230)\end{array}$ \\
\hline $\begin{array}{l}\text { Over-identification test } \\
\text { (test stat and p-value) }\end{array}$ & $\begin{array}{c}3.01 \\
(0.699\end{array}$ & $\begin{array}{c}4.21 \\
(0.520)\end{array}$ & $\begin{array}{c}4.12 \\
(0.532)\end{array}$ & $\begin{array}{c}5.91 \\
(0.315)\end{array}$ & $\begin{array}{c}3.34 \\
(0.342)\end{array}$ & $\begin{array}{c}0.648 \\
(0.421)\end{array}$ \\
\hline $\begin{array}{l}\text { Hausman specification } \\
\text { test } \\
\text { (test stat and p-value) }\end{array}$ & $\begin{array}{l}0.320 \\
(1.00)\end{array}$ & $\begin{array}{l}0.480 \\
(1.00)\end{array}$ & $\begin{array}{l}0.000 \\
(1.00)\end{array}$ & $\begin{array}{l}0.000 \\
(1.00)\end{array}$ & $\begin{array}{l}0.050 \\
(1.00)\end{array}$ & $\begin{array}{l}0.010 \\
(1.00)\end{array}$ \\
\hline $\begin{array}{l}\text { F-test on identifying } \\
\text { instruments } \\
\text { (test stat and p-value) }\end{array}$ & $\begin{array}{l}3.48 \\
(0.006\end{array}$ & $\begin{array}{c}3.29 \\
(0.009)\end{array}$ & $\begin{array}{c}8.93 \\
(0.000)\end{array}$ & $\begin{array}{c}7.64 \\
(0.000)\end{array}$ & $\begin{array}{c}5.81 \\
(0.001)\end{array}$ & $\begin{array}{c}6.61 \\
(0.003)\end{array}$ \\
\hline $\mathrm{N}$ & \multicolumn{6}{|c|}{6,231} \\
\hline \multicolumn{7}{|l|}{ PANEL B } \\
\hline $\begin{array}{l}\text { Cocaine use by } 10 \text { th } \\
\text { grade }\end{array}$ & $\begin{array}{c}-0.350 \\
(-0.140)\end{array}$ & $\begin{array}{c}1.66 \\
(0.580)\end{array}$ & $\begin{array}{c}3.42 \\
(1.08)\end{array}$ & $\begin{array}{c}5.39 \\
(1.70)\end{array}$ & $\begin{array}{l}2.37 \\
(0.720)\end{array}$ & $\begin{array}{c}4.96 \\
(0.690)\end{array}$ \\
\hline $\begin{array}{l}\text { Over-identification test } \\
\text { (test stat and p-value) }\end{array}$ & $\begin{array}{c}3.13 \\
(0.681)\end{array}$ & $\begin{array}{c}3.94 \\
(0.558)\end{array}$ & $\begin{array}{c}2.92 \\
(0.712)\end{array}$ & $\begin{array}{c}2.80 \\
(0.731)\end{array}$ & $\begin{array}{c}2.93 \\
(0.403)\end{array}$ & $\begin{array}{c}0.014 \\
(0.905)\end{array}$ \\
\hline $\begin{array}{l}\text { Hausman specification } \\
\text { test } \\
\text { (test stat and p-value) }\end{array}$ & $\begin{array}{l}0.040 \\
(1.00)\end{array}$ & $\begin{array}{l}0.790 \\
(1.00)\end{array}$ & $\begin{array}{l}0.870 \\
(1.00)\end{array}$ & $\begin{array}{l}1.95 \\
(1.00)\end{array}$ & $\begin{array}{l}0.310 \\
(1.00)\end{array}$ & $\begin{array}{l}0.590 \\
(1.00)\end{array}$ \\
\hline $\begin{array}{l}\text { F-test on identifying } \\
\text { instruments } \\
\text { (test stat and p-value) }\end{array}$ & $\begin{array}{c}36.87 \\
(0.000)\end{array}$ & $\begin{array}{c}25.99 \\
(0.000)\end{array}$ & $\begin{array}{c}6.00 \\
(0.000)\end{array}$ & $\begin{array}{c}6.37 \\
(0.000)\end{array}$ & $\begin{array}{c}6.87 \\
(0.000)\end{array}$ & $\begin{array}{c}1.33 \\
(0.274)\end{array}$ \\
\hline $\mathrm{N}$ & & & & & & \\
\hline
\end{tabular}

1) Huber-White standard errors with adjustment for clustering on state of residence.

2) High school variables: low $10^{\text {th }}$ grade math score, smokes daily in $10^{\text {th }}$ grade, drugs are a problem at this school, offered drugs in $10^{\text {th }}$ grade, punishment for drug possession is expulsion.

3) $8^{\text {th }}$ grade personal variables: repeated a grade, low $8^{\text {th }}$ grade math score, smoked daily in $8^{\text {th }}$ grade, number of times parents were called for behavior problems in $8^{\text {th }}$ grade, drug offer in $8^{\text {th }}$ grade.

4) State policy instruments: midpoint of lowest and highest real fine for marijuana possession, midpoint of longest and shortest jail term for marijuana possession, cocaine price, marijuana decriminalization.

5) School policy instruments: $8^{\text {th }}$ grade school has a drug problem, expulsion is punishment for drug possession in $8^{\text {th }}$ grade school

6) State sentiment variables: average real income, unemployment rate, religious composition of state 


\begin{tabular}{|c|c|c|c|c|c|c|}
\hline \multirow{4}{*}{\multicolumn{3}{|c|}{ 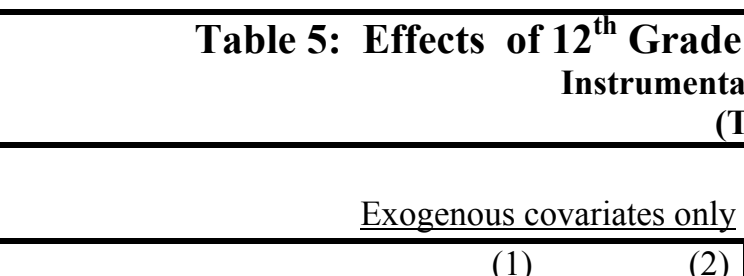 }} & \multirow{2}{*}{\multicolumn{3}{|c|}{ Number of Years of Education }} & \multirow[b]{4}{*}{ (6) } \\
\hline & & & & & & \\
\hline & & & \multicolumn{3}{|c|}{ Full set of covariates } & \\
\hline & & & (3) & (4) & (5) & \\
\hline & $\begin{array}{l}\text { IV w/ } \\
\text { full set of } \\
\text { instruments }\end{array}$ & $\begin{array}{l}\text { Model (1) } \\
\text { w/state } \\
\text { sentiment } \\
\text { variables } \\
\end{array}$ & $\begin{array}{l}\mathrm{IV} \text { w/ } \\
\text { full set of } \\
\text { instruments }\end{array}$ & $\begin{array}{l}\text { Model (3) } \\
\text { w/state } \\
\text { sentiment } \\
\text { variables } \\
\end{array}$ & $\begin{array}{l}\text { IV w/state } \\
\text { policies } \\
\text { only as } \\
\text { instruments }\end{array}$ & $\begin{array}{l}\text { IV w/school } \\
\text { policies only as } \\
\text { instruments }\end{array}$ \\
\hline \multicolumn{7}{|l|}{ PANEL C } \\
\hline $\begin{array}{l}\text { Marijuana use in } 12^{\text {th }} \\
\text { grade }\end{array}$ & $\begin{array}{l}1.95 \\
(0.670)\end{array}$ & $\begin{array}{c}0.934 \\
(0.320)\end{array}$ & $\begin{array}{c}1.44 \\
(0.900)\end{array}$ & $\begin{array}{c}0.547 \\
(0.310)\end{array}$ & $\begin{array}{l}1.00 \\
(0.620)\end{array}$ & $\begin{array}{l}4.72 \\
(0.660)\end{array}$ \\
\hline $\begin{array}{l}\text { Over-identification test } \\
\text { (test stat and p-value) }\end{array}$ & $\begin{array}{c}1.05 \\
(0.959)\end{array}$ & $\begin{array}{c}1.55 \\
(0.907)\end{array}$ & $\begin{array}{c}1.25 \\
(0.940)\end{array}$ & $\begin{array}{c}1.97 \\
(0.854)\end{array}$ & $\begin{array}{c}0.843 \\
(0.839)\end{array}$ & $\begin{array}{c}0.033 \\
(0.857)\end{array}$ \\
\hline $\begin{array}{l}\text { Hausman specification } \\
\text { test } \\
\text { (test stat and p-value) }\end{array}$ & $\begin{array}{l}0.580 \\
(1.00)\end{array}$ & $\begin{array}{l}0.260 \\
(1.00)\end{array}$ & $\begin{array}{l}0.740 \\
(1.00)\end{array}$ & $\begin{array}{l}0.170 \\
(1.00)\end{array}$ & $\begin{array}{l}0.380 \\
(1.00)\end{array}$ & $\begin{array}{c}0.55 \\
(1.00)\end{array}$ \\
\hline $\begin{array}{l}\text { F-test on identifying } \\
\text { instruments } \\
\text { (test stat and p-value) }\end{array}$ & $\begin{array}{c}1.58 \\
(0.176)\end{array}$ & $\begin{array}{c}1.23 \\
(0.307)\end{array}$ & $\begin{array}{c}4.70 \\
(0.001)\end{array}$ & $\begin{array}{c}4.27 \\
(0.002)\end{array}$ & $\begin{array}{c}5.97 \\
(0.001)\end{array}$ & $\begin{array}{c}1.28 \\
(0.289)\end{array}$ \\
\hline $\mathrm{N}$ & \multicolumn{6}{|c|}{4,088} \\
\hline \multicolumn{7}{|l|}{ PANEL D } \\
\hline $\begin{array}{l}\text { Cocaine use by } 12 \text { th } \\
\text { grade }\end{array}$ & $\begin{array}{l}-3.52 \\
(-1.10)\end{array}$ & $\begin{array}{c}-1.74 \\
(-0.640)\end{array}$ & $\begin{array}{c}-0.997 \\
(-0.230)\end{array}$ & $\begin{array}{c}0.100 \\
(0.003)\end{array}$ & $\begin{array}{c}-3.24 \\
(-0.720)\end{array}$ & $\begin{array}{c}4.82 \\
(0.430)\end{array}$ \\
\hline $\begin{array}{l}\text { Over-identification test } \\
\text { (test stat and p-value) }\end{array}$ & $\begin{array}{c}0.576 \\
(0.989)\end{array}$ & $\begin{array}{c}1.41 \\
(0.923)\end{array}$ & $\begin{array}{c}1.85 \\
(0.870)\end{array}$ & $\begin{array}{c}2.07 \\
(0.839)\end{array}$ & $\begin{array}{c}0.700 \\
(0.873)\end{array}$ & $\begin{array}{c}0.427 \\
(0.513)\end{array}$ \\
\hline $\begin{array}{l}\text { Hausman specification } \\
\text { test } \\
\text { (test stat and p-value) }\end{array}$ & $\begin{array}{l}0.490 \\
(1.00)\end{array}$ & $\begin{array}{l}0.070 \\
(1.00)\end{array}$ & $\begin{array}{l}0.020 \\
(1.00)\end{array}$ & $\begin{array}{l}0.020 \\
(1.00)\end{array}$ & $\begin{array}{l}0.260 \\
(1.00)\end{array}$ & $\begin{array}{l}0.280 \\
(1.00)\end{array}$ \\
\hline $\begin{array}{l}\text { F-test on identifying } \\
\text { instruments } \\
\text { (test stat and p-value) }\end{array}$ & $\begin{array}{c}10.16 \\
(0.000)\end{array}$ & $\begin{array}{c}7.33 \\
(0.000)\end{array}$ & $\begin{array}{c}1.83 \\
(0.115)\end{array}$ & $\begin{array}{c}2.15 \\
(0.066)\end{array}$ & $\begin{array}{c}2.51 \\
(0.055)\end{array}$ & $\begin{array}{c}0.310 \\
(0.736)\end{array}$ \\
\hline $\mathrm{N}$ & & & & & & \\
\hline
\end{tabular}

1) Huber-White standard errors with adjustment for clustering on state of residence.

2) High school variables: low $12^{\text {th }}$ grade math score, smokes daily in $12^{\text {th }}$ grade, drugs are a problem at this school, offered to buy drugs, punishment for drug possession is expulsion.

3) $8^{\text {th }}$ grade personal variables: repeated a grade, low $8^{\text {th }}$ grade math score, smoked daily in $8^{\text {th }}$ grade, number of times parents were called for behavior problems in $8^{\text {th }}$ grade, drug offer in $8^{\text {th }}$ grade.

4) State policy instruments: midpoint of lowest and highest real fine for marijuana possession, midpoint of shortest and longest jail term for marijuana possession, cocaine price, marijuana decriminalization.

5) School policy instruments: $8^{\text {th }}$ grade school has a drug problem, expulsion is punishment for drug possession in $8^{\text {th }}$ grade school

6) State sentiment variables: average real income, unemployment rate, religious composition of state 


\begin{tabular}{|c|c|c|c|c|c|c|c|c|}
\hline \multicolumn{9}{|c|}{$\begin{array}{c}\text { Appendix Table } \\
\text { Summary of First Stage Results } \\
\text { OLS Estimate } \\
\text { (T-Statistic) }\end{array}$} \\
\hline & \multicolumn{2}{|c|}{$\begin{array}{l}10^{\text {th }} \text { grade } \\
\text { marijuana use }\end{array}$} & \multicolumn{2}{|c|}{$\begin{array}{c}12^{\text {th }} \text { grade } \\
\text { marijuana use }\end{array}$} & \multicolumn{2}{|c|}{$\begin{array}{c}10^{\text {th }} \text { grade cocaine } \\
\text { use }\end{array}$} & \multicolumn{2}{|c|}{$\begin{array}{c}12^{\text {th }} \text { grade cocaine } \\
\text { use }\end{array}$} \\
\hline & $\begin{array}{l}\text { w/state } \\
\text { sentiment } \\
\text { variables }\end{array}$ & $\begin{array}{l}\text { w/o state } \\
\text { sentiment } \\
\text { variables }\end{array}$ & $\begin{array}{l}\text { w/state } \\
\text { sentiment } \\
\text { variables }\end{array}$ & $\begin{array}{l}\text { w/o state } \\
\text { sentiment } \\
\text { variables }\end{array}$ & $\begin{array}{l}\text { w/state } \\
\text { sentiment } \\
\text { variables }\end{array}$ & $\begin{array}{l}\text { w/o state } \\
\text { sentiment } \\
\text { variables }\end{array}$ & $\begin{array}{l}\text { w/state } \\
\text { sentiment } \\
\text { variables }\end{array}$ & $\begin{array}{l}\text { w/o state } \\
\text { sentiment } \\
\text { variables }\end{array}$ \\
\hline marijuana fine & $\begin{array}{l}-0.001 \\
(-2.66)\end{array}$ & $\begin{array}{l}-0.001 \\
(-2.70)\end{array}$ & $\begin{array}{l}-0.002 \\
(-3.81)\end{array}$ & $\begin{array}{l}-0.002 \\
(-4.30)\end{array}$ & $\begin{array}{l}0.000 \\
(2.87)\end{array}$ & $\begin{array}{l}0.000 \\
(2.45)\end{array}$ & $\begin{array}{l}0.000 \\
(1.08)\end{array}$ & $\begin{array}{l}0.000 \\
(1.16)\end{array}$ \\
\hline $\begin{array}{c}\text { marijuana jail } \\
\text { time }\end{array}$ & $\begin{array}{l}-0.014 \\
(-2.16) \\
\end{array}$ & $\begin{array}{l}-0.010 \\
(-1.37)\end{array}$ & $\begin{array}{l}0.012 \\
(1.20) \\
\end{array}$ & $\begin{array}{l}0.013 \\
(1.32) \\
\end{array}$ & $\begin{array}{l}-0.006 \\
(-1.31) \\
\end{array}$ & $\begin{array}{l}-0.004 \\
(-0.900)\end{array}$ & $\begin{array}{l}0.013 \\
(0.980) \\
\end{array}$ & $\begin{array}{l}0.011 \\
(0.710)\end{array}$ \\
\hline cocaine price & $\begin{array}{l}-0.000 \\
(-0.540)\end{array}$ & $\begin{array}{l}-0.000 \\
(-1.16)\end{array}$ & $\begin{array}{l}0.000 \\
(1.00)\end{array}$ & $\begin{array}{l}-0.000 \\
(-0.440)\end{array}$ & $\begin{array}{l}-0.000 \\
(-0.660)\end{array}$ & $\begin{array}{l}-0.000 \\
(-0.970)\end{array}$ & $\begin{array}{l}-0.000 \\
(-0.290)\end{array}$ & $\begin{array}{l}-0.000 \\
(-0.110)\end{array}$ \\
\hline $\begin{array}{c}\text { marijuana } \\
\text { decriminalization }\end{array}$ & $\begin{array}{l}0.010 \\
(1.42)\end{array}$ & $\begin{array}{l}0.008 \\
(1.08)\end{array}$ & $\begin{array}{l}0.023 \\
(2.52)\end{array}$ & $\begin{array}{l}0.022 \\
(2.13)\end{array}$ & $\begin{array}{l}-0.012 \\
(-2.29)\end{array}$ & $\begin{array}{l}-0.009 \\
(-1.95)\end{array}$ & $\begin{array}{l}-0.010 \\
(-1.11)\end{array}$ & $\begin{array}{l}-0.004 \\
(-0.450)\end{array}$ \\
\hline
\end{tabular}

1) Table shows estimated coefficients from first stage drug use equations that include full set of covariates.

2) Equations were estimated using linear probability models.

3) Huber-White standard errors with adjustment for clustering on state of residence. 
